\title{
NEW VIEWS ON STRATEGIC MANAGEMENT
}

UDC: 005.21

Original Scientific Paper

\author{
Srđan BOGETIĆ ${ }^{1}$, Miloš VORKAPIĆ ${ }^{2}$, Snežana LEKIĆ ${ }^{3}$ \\ ${ }^{1}$ Belgrade Business School, 11000 Belgrade, Kraljice Marije 73, Republic of Serbia \\ E-mail: srdjan.bogetic@bbs.edu.rs \\ ${ }^{2}$ University of Belgrade, Institute of Chemistry, Technology and Metallurgy (ICTM) - Center of Microelectronic \\ Technologies, Belgrade, Republic of Serbia \\ ${ }^{3}$ Belgrade Business School, 11000 Belgrade, Kraljice Marije 73, Republic of Serbia
}

Paper received: 03.10.2017.; Paper accepted: 11.11.2017.

\begin{abstract}
Globalisation is the only economic way for national economies all around the world. The globalisation process is marked by the following characteristics: uneven industrial development, intensive application of information and communications technologies (ICT), the development of innovations, the improvement of productivity, and the need to increase the level of competitiveness. As a result of increased ICT application in business, a new business model - sharing economy - has been established and it is increasingly present in practice. However, these changes have significantly influenced the end users themselves who are more and more demanding when using the Internet, smart phones and tablets while shopping for goods or services. With a view to developing competitiveness, developing countries have to follow the changes of the global market, but they also have to create their own national economy growth models. Alongside national economies, companies also have to adapt to new trends. Companies today face great challenges set to them by both the market and the end users.
\end{abstract}

Keywords: Strategic management, Competitiveness, Globalisation, Information and communications technologies, Business strategies.

\section{INTRODUCTION}

In global business conditions, national economies are constantly faced with new challenges which make the process of managing an organisation more complex. The emergence of new regional economic leaders (China, India) and the creation of new regional alliances of BRIC countries (Brazil, Russia, India, China) have an influence on the new global economic division of power, on the one hand, and on a gap which is still present between the rich and poor countries, on the other hand. Solving economic inequalities and creating economic balance is one of the imperatives of the global economic policy. Competitiveness is an imperative in companies' contemporary business practices. Increasing the level of competitiveness of the national economy is an imperative for the countries and all their efforts are concentrated on it. The critics of economic globalisation are in fact those countries which cannot be competitive on the global market and are thus searching for excuses for their failures in big competition and its inequality. National competitiveness itself cannot be achieved without increasing companies' productivity and efficiency which requires constant improvement of employees' skills, application of new innovative solutions and introduction of new technologies in business.

Productivity is the ultimate engine of growth in the global economy. Raising productivity is therefore a fundamental challenge for countries going forward, (OECD, 2015). According to Klaus Schwab, restoring global economic growth will be a challenge for leaders. Permanently diminished growth translates into permanently lower living standards: with 5\% annual growth, it takes just 14 years to double a country's GDP; with 3\% growth, it takes 24 years. If our current stagnation persists, our children and grandchildren might be worse off than their predecessors, (Schwab, 2017). 
Business environment is constantly changing. The changes are heavily influenced by the technological advancements and the process of unification of the global market. These changes are permanent and business organisations have to create behaviour models relative to perceived and expected changes. Some changes in the business environment are increasingly prominent and intensive. The causes of these changes can be found in the intensive technological development, changes in the competition in the late nineties and the effects of the world economic crisis from 2008. The world has come to a new economic level, so national economies have become tightly connected. Business organisations wishing to keep their competitive ability in the long run should dedicate more attention to the changes in the environment, (Đorđević et al., 2016).

The changes in business are constant. It is considered that revolutionary changes in the organisation of work effort have been happening since the early 1990s, (Thompson et al., 2008). The main task of company's management is to coordinate their business model with the demands of a turbulent market.

In the conditions of new changes on the global market, companies have to adjust and create new business strategies which will improve their competitiveness. Companies' new business strategy includes several factors which are equally connected and reach the areas such as:

- ICT application with a view to companies' more efficient preparation for the new $4^{\text {th }}$ industrial revolution;

- Executive managers' orientation towards the global or regional context;

- Improving companies' growth or profitability;

- Locating potential threats and finding the solutions for them.

However, what brings controversy into global business is the role of a new business model sharing economy. Fundamentally, sharing economy platforms use internet, smartphone, and software technologies to create marketplaces that facilitate transactions between numerous peers decentralized buyers and sellers who are frequently individuals or small entities. This new business model enables completing business transactions without intermediaries under favourable financial conditions. The famous consulting house Pricewaterhouse Coopers estimates that sharing economy marketplaces focus on five sectors peer-to-peer finance, online staffing, peer-to-peer accommodation, car sharing, and music/video streaming, (Federal Trade Commission, 2016).

Countries in transition have to focus on a couple of areas when creating their strategic economic model which will enable national competitiveness:

- Increasing the productivity of manufacturing companies;

- Applying international standards (ISO 9001, ISO 14001, HACCP, Global Gap and the like);

- Constant improvement of employees' skills;

- Encouraging innovations as the driving force of companies' productivity and competitiveness;

- Developing infrastructure as a prerequisite for successful business operations;

- Developing companies' awareness about the importance of ICT in business;

- Caring for equal economic development with a view to decreasing poverty and economic inequality;

- Creating legal frames which enable a fair market game.

\section{THE ANALYSIS OF NEW COMPETITIVE RELATIONS ON THE GLOBAL MARKET}

Economic globalisation is the result of social productivity growth, which mostly happened owing to scientific and technological advancement and not owing to any individual or countries. It is the driving force of global growth and it facilitates the flow of goods and capital, advancements in science, technology and civilisation and interaction between people. The consequences of the global economic impact have been felt equally by both developed and developing countries. The most pressing ongoing task put before the global economic leaders is to steer the global economy out of difficulties. Furthermore, as a result of global economy problems, the gap between the poor and the rich countries, i.e. between the South and the North is widening.

The main causes of global economic problems are three critical issues in the economic sphere, which still haven't been effectively addressed, (Jiping, 2017):

1) Lack of robust driving forces for global growth makes it difficult to sustain the steady growth of the global economy; 
2) Inadequate global economic governance makes it difficult to adapt to new developments in the global economy;

3) Uneven global development makes it difficult to meet people's expectations for better lives.

Global economy today is characterised by slow developmental growth and especially by the insufficient growth of the global trade. Reasons for this situation can be found in ineffective short-term policy stimuli and structural reforms which are unfolding too slowly. With a view to solving bad economic indicators, global economy is now searching for new growth drivers, since the traditional engines to drive growth have weakened. New technologies, which were seen as the new sources of growth, still haven't risen up to the task. Estimates show that emerging markets and developing countries contribute to 80 percent of the growth of the global economy. Also, the global economic landscape, characterised by the emergence of new economic leaders (China, Russia, India), regional alliances (BRIC) and rapid development of new technologies, has seriously changed compared to the previous period. Unfortunately, the global governance system has not embraced those new changes which have an influence on insufficient representation and inclusiveness.

Table 1 shows the projection of the real gross domestic product (GDP) growth presented by the OECD (Organisation for Economic Co-operation and Development) experts. The projection of GDP growth has shown a trend where India, China and Indonesia stand out compared to other countries. Some countries have succeeded to repair their economic situation in that period (such as Brazil and Russia), while a fall of GDP's growth is predicted in countries such as Turkey and Mexico.

Table 1: Projection of real GDP growth

\begin{tabular}{|c|c|c|c|c|}
\hline & 2015 & 2016 & 2017 & 2018 \\
\hline World & 3.1 & 3 & 3.5 & 3.6 \\
\hline Brazil & -3.8 & -3.6 & 0.7 & 1.6 \\
\hline Russia & -2.8 & -0.2 & 1.4 & 1.6 \\
\hline India & 7.9 & 7.1 & 7.3 & 7.7 \\
\hline China & 6.9 & 6.7 & 6.6 & 6.4 \\
\hline Indonesia & 4.9 & 5 & 5.1 & 5.2 \\
\hline Japan & 1.1 & 1 & 1.4 & 1 \\
\hline Korea & 2.8 & 2.8 & 2.6 & 2.8 \\
\hline Mexico & 2.7 & 2 & 1.9 & 2 \\
\hline Turkey & 5.9 & 3.1 & 3.4 & 3.5 \\
\hline SAD & 2.6 & 1.6 & 2.1 & 2.4 \\
\hline EU & 1.5 & 1.7 & 1.8 & 1.8 \\
\hline
\end{tabular}

The famous consulting house Pricewaterhouse Coopers $(\mathrm{PwC})$, gave a projection of the long-term global economic development in its 2017 report, where it was indicated that the emerging markets compared to developed economies will dominate on the global level. Table 2 gives a projection of global economic growth (in purchasing power parity) where we can see the increase of developing countries and emerging markets. The following countries belong to the emerging markets and developing countries (E 7): Brazil, China, India, Indonesia, Mexico, Russia and Turkey; while the following countries belong to the G7 group: Canada, France, Germany, Italy, Japan, the UK and the US. The PwC report data show that countries with the biggest growth on the GDP growth list will be: Vietnam - progress from the $32^{\text {nd }}$ place $(2016)$ to the $20^{\text {th }}$ place $(2050)$, the Philippines - from the $28^{\text {th }}$ place $(2016)$ to $19^{\text {th }}$ place (2050) and Nigeria - from the $22^{\text {nd }}$ place (2016) to $14^{\text {th }}$ place (2050). However, by analysing the first ten countries we can perceive that according to the estimate, in 2050 there will be only 3 European countries (Russia, Germany and Great Britain), while China and India will stand out as the two leading countries. If we were to analyse it by region, we could conclude that BRIC countries (Brazil, Russia, India and China) will have an increasingly important role in the global economy. Here, we should particularly take care of the market size that they together have.

Table 2: Estimated global economic growth by 2050 (GDP in purchasing power parity)

\begin{tabular}{|l|c|c|l|}
\hline State & $\mathbf{2 0 1 6}$ & $\mathbf{2 0 5 0}$ & State \\
\hline China & 1 & 1 & China \\
\hline USA & 2 & 2 & India \\
\hline India & 3 & 3 & USA \\
\hline Japan & 4 & 4 & Indonesia \\
\hline Germany & 5 & 5 & Brazil \\
\hline Russia & 6 & 6 & Russia \\
\hline Brazil & 7 & 7 & Mexico \\
\hline Indonesia & 8 & 8 & Japan \\
\hline Great Britain & 9 & 9 & Germany \\
\hline France & 10 & 10 & Great Britain \\
\hline
\end{tabular}

Source: Hawksworth et al., 2017., p. 4

According to the founder of the World Economic Forum in Davos, Klaus Schwab, this round of industrial revolution will produce extensive and far-reaching impacts, such as growing inequality, particularly, the possible widening gap between profit and employees' salaries. The richest one percent of the world's population owns more wealth than the remaining 99 percent. Inequality in 
income distribution and uneven development space are worrying. Over 700 million people in the world are still living in extreme poverty. It is also what is behind the social turmoil in some countries, (Jiping, 2017). With a view to solving global economy problems, it is necessary to find the driving force for development, but also create a balanced development which will ensure that all people have equal access to opportunities and share in the benefits of development. It is necessary to create an economically balanced model which will satisfy the area of sustainable economic business which incorporates: the issue of excessive influence of capital on the making of key decisions, unemployment, decreasing the technological gap between countries, environmental concerns and the rule of law. Industrial transformation creates new labour opportunities, but also increases the number of risky jobs and lay-offs. Some people blame globalisation for the chaos in the world. They consider it to be the Pandora's Box. Neither the migration crisis nor the financial crisis was caused by globalisation. The financial crisis occurred because of the excessive chase for profit and failures in financial regulations. Globalisation is not the cause of economic problems manifested in the limited industrial growth. Global economy has been slowed down for a long time, and the culprits for this situation should be sought in the lack of robust driving forces, the lack of governance systems and uneven global growth, (Jiping, 2017).

When talking about strategic ways of global economic development, it is necessary to mention one which is actually the key one - innovations. Innovations are the foundation of global economy's industrial development. Table 3 shows the first ten countries in 2017 according to the innovation level, based on the methodology done by the World Intellectual Property Organisation (WIPO), Cornell University and INSEAD. The report includes 128 countries and table 3 shows that European Union (EU) countries are dominant in this area too and that Switzerland kept its last year's position. China, as one of the global economy leaders, was on the $25^{\text {th }}$ place in 2016 , but it climbed 3 places ( $22^{\text {nd }}$ place) in 2017. Contrary to China, South Korea is on the $11^{\text {th }}$ place for two years already which confirms its excellent position in the area of innovations.
Table 3: Global innovation index in 2017

\begin{tabular}{|c|l|}
\hline No & State \\
\hline 1. & Switzerland (1) \\
\hline 2. & Sweden (2) \\
\hline 3. & Holland (9) \\
\hline 4. & USA (4) \\
\hline 5. & Great Britain (3) \\
\hline 6. & Denmark (8) \\
\hline 7. & Singapore (6) \\
\hline 8. & Finland (5) \\
\hline 9. & German (10) \\
\hline 10. & Ireland (7) \\
\hline
\end{tabular}

Source: Cornell University, INSEAD, and WIPO, 2017, p. XVIII

\section{INFORMATION TECHNOLOGIES AS TOOLS IN ESTABLISHING COMPANIES' NEW BUSINESS STRATEGIES}

Global economy market has shown that there is no clear boundary between industrial sectors anymore, since the companies which deal with digital technologies are entering into other sectors suggesting new values. As a result of cooperation between the old and the newly-arrived business partners, the new value has to be redefined through a value chain. Technology is the most dynamic factor of economic development and the achievements in the area of high technology and clean technologies influence the creation of completely new markets or new product applications. Digital technologies have created new markets and unprecedented business opportunities. In Europe, the key challenge is to ensure that such opportunities are fully captured by industry and service companies, leveraging digitalisation to create growth and new jobs, (European Commission, 2017). The development of information and communications technology (ICT), as well as the emergence of companies Uber and Airbnb, have used the advantages of applying this industry in business which has led to a new business model known as sharing economy. As a result of that, we have a division on sharing economy sector and traditional rental sector on the global market. A sharing economy marketplace involves three important factors: the platform, which provides the marketplace, the buyers (also referred to in varying contexts as consumers, riders, or renters), and the sellers (also referred to in varying contexts as suppliers, providers, or hosts). The buyers and sellers are typically individuals or small entities who transact over the platform. A platform provides a discrete set of 
services to the parties using it, facilitating their efforts to transact effectively and efficiently, including searching for potential transacting partners, agreeing to terms with them, and performing the contract. To facilitate transactions, a platform is designed to provide an online marketplace that buyers and sellers can access by employing various internet-connected digital communications devices (e.g. smart phones, tablets and the like).

PricewaterhouseCoopers (PwC) data show that key sharing economy sectors (peer-to-peer finance, online staffing, P2P accommodation, car sharing and music/video streaming) generated $\$ 15$ billion in revenues worldwide in 2013. On the other side, the traditional rental sector (equipment rental, B\&B and hostels, book rental, car rental and DVD rental) generated $\$ 240$ billion. However, it is estimated that by 2025 , the sharing economy sector will generate $\$ 335$ billion, which will be identical to the traditional rental sector, (Mcardle, 2015). The European Union compared to the USA has a big gap when it comes to investments in the ICT area. This is why the European Commission has decided to invest 335 billion Euros in this sector with the aim of raising the level of global competitiveness. This investment is considered to be one of the ways in which it is possible to empower existing companies for the new technological period, as well as to reskill their workforce for the technological industry. Strategic Policy Forum on Digital Entrepreneurship has pointed out the existence of a digital skills gap in their research. As a result of computerisation of key technological advances, 54\% of European businesses are at risk of closing down. $77 \%$ of the overall number of the surveyed companies considered missing digital skills as the key hurdle to their digital transformation. Furthermore, the data which confirms the big digital skills gap between EU companies is that only $4 \%$ of companies have ensured that their training efforts are aligned with their overall digital strategy (Europenan Commission, 2016). As a result of the gap in the area of computer skills knowledge, EU economy will have four big problems:

1. The lack of competitiveness of companies and national economies of EU member countries;

2. The existing (manual) jobs becoming obsolete, which influences the change in the way certain industries do their business, but also the change in the labour market itself (between 30 and 90 million people, i.e. $10 \%$ and $30 \%$ );
3. The process of digitalisation will create new types of skills which will contribute to the need to reskill and re-employ the redundant workforce;

4. The average involvement of women in digital industry is only $15 \%$ which is unfortunately not enough and makes the solution of the digital gap problem more difficult.

Reskilling the workforce in different EU industrial sectors is a major priority and challenge. The reason for this kind of EU attitude towards new skills lies in the fact that in that way they can mitigate the economic and social risks that will come from failing to prepare the workforce for the digital future. All trainings which could be held with a view to empowering the workforce for the digital industry have to be connected with the needs of the industry. Unfortunately, the society is still unaware of the problem they're facing, which is confirmed by the fact that employees in the new global business conditions have to be ready to reskill and shift to other industrial sectors (Europenan Commission, 2016).

\section{CHALLENGES IN THE AREA OF MANAGING AN ORGANISATION IN THE FUTURE}

Companies wanting to prevail on the turbulent market, in the conditions of constant changes, have to establish a business philosophy facing the global market, customer satisfaction, increase of productivity and business quality. The creator of the concept of reengineering, Michael Hammer (Hammer \& Champy, 2004), states that America's main business problem is that it is entering the twenty-first century with companies designed during the nineteenth century to work well in the twentieth. We need something entirely different. Starting from this statement, contemporary business demands flexible and innovative business organisations, focused on the processes and the user and guided by the constant improvement of business quality based on the improvement of work productivity and knowledge. When managing processes, the key structural question is no longer centralisation vs. decentralisation, but standardisation vs. diversification.

Today's turbulent and dynamic market environment forces companies to look for more comprehensive and complex tools for managing all their activities and processes. The need for more precise and faster decisions is stronger than ever. 
In that direction, almost every aspect of company functioning experiences dramatic changes (Mitkovska-Trendova et al., 2014).

The traditional organisation, founded on establishing strong command lines and focused on activities, changes into a new organisation focused on processes, with a direct approach to customers, managed by lead teams and based on multitasking and outsourcing. The organisation has to be open for networking - cooperation with the users, the suppliers and the competition is necessary.

According to certain beliefs (Thompson et al., 2008), the characteristics of the organisation of the future are the following:

- Fewer barriers between the vertical levels, functions, business units,

- The ability to change and learn faster,

- Cooperative effort between people on different functions.

The challenges that the companies are faced with in the following period are:

- Preparing companies for the arrival of the $4^{\text {th }}$ industrial (digital) revolution;

- Companies' dilemma whether to direct their business towards the global or the regional market;

- Global trends that influence business (political and economic);

- Brand care;

- Application of new management concepts with a view to accomplishing business excellence.

Some authors (Schwieters et al., 2017), think that the next ten principles will enable managers a simpler company preparation for the period of new industrial revolution:

1. Rethink your business model.

2. Build your strategy around platforms.

3. Design for customers.

4. Raise your technological acumen.

5. Innovate rapidly and openly.

6. Learn more from your data.

7. Adopt innovative financing models.

8. Focus on purpose, not products.

9. Be trustworthy with data.

10.Put humanity before machines.

Today, brands occupy an important function in contemporary business for the following reasons: they attract new customers, they build loyalty with existing customers, they motivate employees to work better and more efficiently, and they also earn significant revenue. Companies that want to keep their brands on the global market have to invest financial means into design and promotion.

The position of brands has not come at the price of diversity. The world is not one flat plane, but it is made up of a tapestry of markets, cultures, likes, dislikes, and preferences. In managing the brand on a global or even a regional basis, decisions must be made regarding whether the brand is to be a shield for a range of products that are similar yet different enough to cater to particular markets, or whether the same product is sold and distributed in each but using different marketing strategies, such as a different brand name, a different logo, or even different packaging (Omae, 2007).

Table 4 shows 10 most valuable brands and we can notice that the industry of technology has most brands (5), as well as that the first three brands stand out in comparison with the others by their value. Moreover, it can be seen that the USA is the country with the largest number of most valuable brands. When talking about the overall presence of industries on the list of 500 global brands, five of them stand out: technologies, banks, telecoms, retail and auto industry.

Chinese banks' brand value growth has been rapidly outpacing that of European and North American competitors. The nation's vast population, organic expansion, foreign M\&A activity and positive relationships with Chinese consumers are a few common attributes Chinese banks share which serve to explain the immense growth of this industry (Brand Finance, 2017).

Some companies that were long considered to be most valuable brands, such as Coca-Cola, have not managed well with new trends that have changed the market of non-alcoholic beverages over the last 10 years. New customer demands for unsweetened beverages and healthy products have forced the company to make alternative products such as Coca- Cola Zero Sugar and by doing so make an increase in Europe, Middle East, Africa and Latin America. However, Coca-Cola has simultaneously launched new orange juices and increased the presence of its thickened and premium juices under the 'Innocent' brand in West Europe. 
Table 4: Top 10 most valuable brands in 2017 (USD millions)

\begin{tabular}{|c|c|l|l|c|r|}
\hline $\begin{array}{c}\text { Rank } \\
\mathbf{2 0 1 7}\end{array}$ & $\begin{array}{c}\text { Rank } \\
\mathbf{2 0 1 6}\end{array}$ & $\begin{array}{c}\text { Name of } \\
\text { the brand }\end{array}$ & Industry & Country & $\begin{array}{c}\text { Value of } \\
\text { the brand }\end{array}$ \\
\hline 1 & 2 & Google & Technology & USA & 109,470 \\
\hline 2 & 1 & Apple & Technology & USA & 107,141 \\
\hline 3 & 3 & Amazon.com & Technology & USA & 106,396 \\
\hline 4 & 6 & AT\&T & Telecoms & USA & 87,016 \\
\hline 5 & 4 & Microsoft & Technology & USA & 76,265 \\
\hline 6 & 7 & $\begin{array}{l}\text { Samsung } \\
\text { Group }\end{array}$ & Conglomerate & $\begin{array}{c}\text { South } \\
\text { Korea }\end{array}$ & 66,219 \\
\hline 7 & 5 & Verizon & Telecoms & USA & 65,875 \\
\hline 8 & 8 & Walmart & Retail & USA & 62,211 \\
\hline 9 & 17 & Facebook & Technology & USA & 61,998 \\
\hline 10 & 13 & ICBC & Banks & China & 47,832 \\
\hline
\end{tabular}

Source: Brand Finance, 2017

The question of employee satisfaction with the work ambiance in the company is an important segment in the process of improving competitiveness. Companies, and even industries, are taking this issue more and more seriously. Many companies, such as Google, Hilton, Hyatt, Boston Consulting Group, Edward Jones and the like have gained the reputation of desirable employers. With this kind of image, companies do not have a problem with employing quality workers. In practice, it can be seen that most profitable companies are not always the ones attractive to potential employees. Creating the ambiance where employees are satisfied with their working environment, the relationship with their superiors, as well as with the benefits the company offers is considered necessary for the companies which want to be competitive on the global market in the long run. The key creator of such company relationship towards employees is the owner of the company or the general manager who create that company policy. Table 5 shows a list of 10 best companies to work for. Google is on this list for 11 years already, 6 of which it has been on the first place. A research done by Google (a sample of 1,064 participants) showed that $98 \%$ of the interviewees think that working for this company is a great challenge, that it instils the feeling of pride and that the atmosphere is great.

Table 6 shows the presence of companies according to industries and three stand out in particular: professional services (18 companies), financial services (17 companies) and insurance and IT (15 companies).
Table 5: Best companies to work for

\begin{tabular}{|c|c|c|c|c|}
\hline No & Company & Activity & Employees & Employees" \\
\hline 1 & Google & IT & 72.053 & 1.000 \\
\hline 2 & \begin{tabular}{|l|} 
Wegmans \\
Food Markets
\end{tabular} & Retail & 46.800 & 2.000 \\
\hline 3 & \begin{tabular}{|l|} 
The Boston \\
Consulting \\
Group \\
\end{tabular} & $\begin{array}{l}\text { Professional } \\
\text { services }\end{array}$ & 12.000 & 1.000 \\
\hline 4 & Baird & \begin{tabular}{|l} 
Financial \\
services and \\
insurance
\end{tabular} & 3.311 & 119 \\
\hline 5 & Edward Jones & \begin{tabular}{|l|} 
Financial \\
services and \\
insurance
\end{tabular} & 43.090 & 1.680 \\
\hline 6 & Genentech & $\begin{array}{l}\text { Biotechnology } \\
\text { and } \\
\text { pharmaceutical } \\
\text { products }\end{array}$ & 14.815 & 1.268 \\
\hline 7 & \begin{tabular}{|l|} 
Ultimate \\
Software
\end{tabular} & IT & 3.860 & 450 \\
\hline 8 & \begin{tabular}{|l|} 
Salesforce \\
\end{tabular} & IT & 22.070 & 1.292 \\
\hline 9 & Acuity & \begin{tabular}{|l|} 
Financial \\
services and \\
insurance
\end{tabular} & 1.244 & 70 \\
\hline 10 & Quicken Loans & $\begin{array}{l}\text { Financial } \\
\text { services and } \\
\text { insurance }\end{array}$ & 13.690 & 849 \\
\hline
\end{tabular}

Table 6: Distribution of companies according to industries

\begin{tabular}{|l|c|}
\hline Industry & $\begin{array}{c}\text { Number of } \\
\text { companies }\end{array}$ \\
\hline $\begin{array}{l}\text { Biotechnology and pharmaceutical } \\
\text { products }\end{array}$ & 4 \\
\hline Construction and real estate & 4 \\
\hline Education and training & 1 \\
\hline Electronics & 1 \\
\hline Financial services and insurance & $\mathbf{1 7}$ \\
\hline Health protection & 11 \\
\hline Hotel industry & 6 \\
\hline IT & $\mathbf{1 5}$ \\
\hline Production & 5 \\
\hline Media & 1 \\
\hline Professional services & $\mathbf{1 8}$ \\
\hline Retail & 12 \\
\hline Telecoms & 1 \\
\hline Transport & 3 \\
\hline Other & 1 \\
\hline
\end{tabular}

Source: Fortune

"20 years inside the mind of the CEO: What's next?" survey conducted among the CEOs in 2017 by Pricewaterhouse Coopers, has shown their attitudes concerning issues of global business. $44 \%$ out of the overall number of participants say that globalization has not helped to close the gap between rich and poor, while 54\% don't think growth matters much, if at all, for their well-being. Furthermore, the participants $(78 \%)$ believe that globalisation has helped to create a skilled and educated workforce (of which $29 \%$ believed to a large extent) as well as that it has helped create full 
and meaningful employment (64\%). The interviewed CEOs (69\%) think it's harder for businesses to sustain trust in the digital age, $(\mathrm{PwC}$, 2017).

The interviewees' attitude towards globalization included three important areas:

- The attitude towards the gap between the rich and the poor which confirms the theses given on the World Economic Forum in Davos in 2017;

- A constant improvement of knowledge is necessary in order to adapt to new global trends;

- The end users are becoming increasingly informed due to the influence of the digital age and due to a great competition, their loyalty is limited.

In the survey, the interviewees had the possibility to answer the question which activities, if any, they are planning in the future (12 months) in order to drive corporate growth or profitability. Two activities which the CEOs would implement stood out, (PwC, 2017):

- Organic growth $-79 \%$

- Cost reduction $-62 \%$

- New strategic alliance or joint venture $-48 \%$

- New M\&A - 41\%

- Collaboration with entrepreneurs or start-ups $28 \%$

- Outsourcing - $17 \%$

- Selling a business or exiting a market $-15 \%$

- None of the above $-1 \%$

The activity of cost reduction can be explained by the CEOs' wish for a more rational business and greater application of IT in business, but also with transport and logistics development. After the world economic crisis from 2008, companies take care about this in order to increase efficiency. According to Đuričin et al. (2016), organic (or internal) growth is the consequence of company's internal strength to use the sources of competitive advantage through their own investments in tangible and intangible assets. Organic growth can be accomplished on three levels: by investing in new capacities; by investing in capacity extension and capacitance which enables entering new activities.

CEOs have also expressed their concerns about economic, political, social, environmental and business threats that can influence their companies' growth prospects. Uncertain economic growth $(82 \%)$ and over-regulation $(80 \%)$ stand out when compared to others. Other threats include, $(\mathrm{PwC}$, 2017):

- Uncertain economic growth - 82\%

- Over-regulation - $80 \%$

- Availability of key skills - $77 \%$

- Geopolitical uncertainty - 74\%

- Speed of technological change - 70\%

- Increasing tax burden - 68\%

- Exchange rate volatility - 70\%

- Social instability - $68 \%$

- Changing consumer behaviour - $65 \%$

- Cyber threats $-61 \%$

The most common threats mentioned by the CEOs indicate the need for a more efficient organisation of the global market, but also the need for both national economies and regional markets (EU, ASEAN and the like) to eliminate bureaucracy which makes business more difficult.

\section{THE APPLICATION OF NEW BUSINESS STRATEGIES FOR COMPANIES IN TRANSITION COUNTRIES}

Since the beginning of the global financial crisis (2008), which lasts even today in certain segments, companies' strategies have mainly focused on lowering costs and creating suitable business models which would enable them to adapt to new market trends. The largest number of companies has used the models of downsizing, outsourcing and integration, with a view to increasing business efficiency, lowering the costs and surviving on the market, but also achieving competitive advantage on the market. When talking about national economy strategies, depending on their economic, political and raw material potential, they can choose from the following three strategies: globalisation $(100 \%)$, semi-globalisation $(10 \%)$ and regionalisation. Globalisation (100\%) is the strategy used the most by large economic powers like Japan, China, USA and Russia, which are in that way showing their economic and political power. Harvard Business School professor, Pankaj Ghemawat, is of the opinion that semiglobalisation is the real state of the world where borders still matter, (Ghemawat, 2010).

When talking about business strategies of transition countries such as the Republic of Serbia, the Federation of Bosnia and Herzegovina, Montenegro, Croatia and Albania, but also 
countries from other continents similar in economic power, the regionalisation strategy is a good start of business internationalisation. When talking about Western Balkan countries, the regionalisation strategy can be achieved in three directions: joining the European Union (EU), Eurasian countries and the CEFTA Agreement. According to the data of the Statistical Office of the Republic of Serbia (SORS), the biggest export partners of the Republic of Serbia in 2017 are: the European Union \$707.6 million, MEDA (Economic Association of Mediterranean Countries) \$130.2 million and WBCs (Western Balkan Countries + Moldova $=$ members of the CEFTA agreement) \$139.8 million, APEC (AsiaPacific Economic Cooperation) $\$ 91.3$ million, (SORS, 2017a). On 19 December 2006, Serbia became the member of a unique multilateral Free Trade Agreement in South-East Europe, CEFTA 2006, together with eight other countries (Albania, Bosnia and Herzegovina, Bulgaria, Croatia, Macedonia, Moldova, Montenegro, Romania, Serbia and UNMIK/Kosovo as a customs territory in accordance with the Resolution SB OUN n. 1244). CEFTA Agreement defines general obligations relating to the trade of all goods. The general rule is that quantity limits, customs duties and other import and export duties will be abolished in the trade between the countries in the region and that new limitations will not be introduced. For the economy of the Republic of Serbia, but also Western Balkan countries, the imperative should be pooling around products or services and a joint appearance on the EU market, i.e. certain member countries, but also certain countries of the Eurasian alliance, such as Belarus, Russia and Kazakhstan. Individual countries themselves do not have enough economic power and potential to appear on the EU or Eurasian market. The data of the Ministry of Finance of the Republic of Serbia show that the EU was the biggest export partner in 2016 (66.1\%) which is an increase $(0.4 \%)$ compared to the previous year, (Ministry of Finance, 2017). According to the data of the Ministry of Finance of the Republic of Serbia, on the list of 10 biggest foreign trade partners, as many as 7 countries are from the EU market, while the other partners are the Russian Federation, China and Bosnia and Herzegovina. However, when talking about the EU market, we mostly mean the markets of the neighbouring countries - Italy, Germany, Croatia, Slovenia, Hungary, Romania and Poland. Germany and Poland stand out from the others as foreign trade partners.
CEOs of domestic companies have listed the biggest markets in one survey and Croatia stood out as the most important market, where $31 \%$ of interviewees sees an opportunity for investment. Among the three most important markets was also Germany, mentioned by $26 \%$ of CEOs, while Russia is still, besides all difficulties, one of the three most important markets the CEOs in Serbia want to enter. When talking about investments in the Republic of Serbia, only 5\% of business leaders from the Central-East Europe region and $14 \%$ from the South-East Europe, mentioned it as the most important market they want to enter in the future (PwC, 2016).

The first five divisions of export products are: road vehicles (10.2\%), electrical machines, apparatus and devices $(8.3 \%)$, fruits and vegetables $(5.4 \%)$, cereals and products based on cereals $(4.7 \%)$ and power-generating machines and devices (4.5\%), with the export value of 4,459.3 million Euros (33.1\% of total export). Agricultural production is the main contributor to the export growth in the fourth quarter, followed by the production of basic metals and electrical equipment. A third of the basic metals export value is exported by Hesteel Ironworks, while a half of electrical equipment export value is exported by three companies Siemens, Gorenje and Robert Bosch (Ministry of Finance, 2017). On the list of the first 10 products in exports, the first place belongs to ignition wiring sets for planes, vehicles and ships (USD 52 million); the second to diesel cars up to $1500 \mathrm{~cm}^{3}$ (USD 40 million), on the third place is the refined copper export with the value of USD 24 million, followed by new tyres for passengers' cars, also with the value of USD 24 million; the next one is the export of hot-rolled products in coils (iron and unalloyed steel) which amounted to USD 17 million, which is the same value for the frozen raspberries export; export of cars, candle burning over 1000 but below $1500 \mathrm{~cm}^{3}$ also amounted to USD 17 million, which is also the export value for parts of seats; the export of fresh apples amounted to USD 16 million and the last place belongs to the export of plastic coated paper and cardboard, worth USD 15 million (SORS, 2017b). The data from the Ministry of Finance of the Republic of Serbia for 2016 showed that the export value of the 15 biggest exporters in 2016 was 3.9 billion Euros. As can be seen in table 1, FCA Srbija is the biggest exporter, while other companies are far behind in the export area. The company FCA Srbija from Kragujevac produces road vehicles of the Fiat 
500L brand, but the problem is that the company only assembles car parts. The production is mostly done in other countries, which has a negative influence on the companies in the machine industry, automotive industry and other industries that would be interested in participating in the production. Only a small number of domestic companies can compete with the FCA Srbija and that only in the production of certain components, such as cables, seats, electro equipment and the like. This example is to show that to the Republic of Serbia, globalisation does not offer the opportunities of a sophisticated production and that we have to aim our strategies in two different directions - the manufacturing industry and the production of components.

Table 7: The first five biggest exporting companies in the Republic of Serbia in 2016

\begin{tabular}{|c|l|l|c|}
\hline No. & Name of the exporter & Place & $\begin{array}{c}\text { Value } \\
\text { (mill. Eur) }\end{array}$ \\
\hline 1. & FCA Srbija d.o.o. & Kragujevac & $1,068.3$ \\
\hline 2. & $\begin{array}{l}\text { Hesteel Serbia Iron \& } \\
\text { Steel d.o.o. Belgrade* }\end{array}$ & Belgrade & 368.7 \\
\hline 3. & Tigar Tyres & Pirot & 315.7 \\
\hline 4. & Naftna industrija Srbije & Novi Sad & 235.8 \\
\hline 5. & Philip Morris Operations & Niš & 220.2 \\
\hline \multicolumn{3}{|c|}{$\begin{array}{l}\text { Source: Ministry of Finance, 2017, p. 25 } \\
\text { *from July 2016, the company Železara Srbije operates } \\
\text { under the new name of Hesteel Serbia Iron \& Steel }\end{array}$}
\end{tabular}

When talking about production on the market of the Republic of Serbia, it is necessary to point out the activities in the textile industry sector which had $4 \%$ in export structure in the previous year, but where the production is mostly based on contract work. This form of business has its good and bad sides. The good side is that when the company does not have a branded product and a market, there is still an opportunity to work and sustain the company on the market. However, the problem is that the company does not have the opportunity to implement innovations in production processes in these activities and thus loses the technological pace with the competition, as well as the motivation of the employees to improve the production processes. Contract work is usually used in countries where workforce engagement is much cheaper than in developed economies. The research on ICT usage in companies, conducted by the Statistical Office of the Republic of Serbia in 2016 , on a representative sample of 1,673 companies, also touched upon the companies' attitude to provide any kind of training for the employees who are not ICT experts, with a view to developing ICT skills. When talking about the industries where the training of employees who are not ICT experts is most prevalent, the most prominent ones are: the sector of accommodation service and food (45.2\%) and the sector of information and communications $(40.9 \%)$. However, if we want to increase the level of ICT skills in domestic companies, it is necessary that the companies get more involved in this area. From the total number of surveyed companies, only $27.5 \%$ of companies take care about providing ICT skills for the employees who are not ICT experts which is not enough and presents an additional problem for the application of new technologies in business operations, (Kovačević et al., 2016).

"Redefining business success in a changing world" survey conducted in 2016 by Pricewaterhouse Coopers among 1,409 CEOs in the world and 42 CEOs in the Republic of Serbia (only those whose revenue was bigger than 7 billion USD) showed their attitudes related to activities influencing global business operations. The survey itself was done in the period from September to December 2015.

CEOs are not very optimistic when talking about the global industrial growth in current business conditions. However, contrary to the majority, CEOs in Serbia (31\% and 36\% in SEE region) (with Romania on the top of the ladder - 50\%) show somewhat more optimistic attitude. (PwC, 2016).

Table 8 shows the greatest threats for business according to the opinion of interviewed CEOs. As can be noticed, the geopolitical crisis and overregulation are the greatest obstacles for business. Taking into consideration that this survey was done in 2015, events later on have confirmed these fears even more, such as Brexit, migration crisis, the new President of the USA and his attitude to global issues (like environmental protection) and similar. The issue of over-regulation indicates the inefficiency of national economies which in this way hamper companies and put a stop to their strategic plans. The industry of Republic of Serbia is still not done with transition so it should not come as a surprise that the greatest problem is still social instability. In the conditions of inexistent market ambience which entails healthy institutions, laws and free competition, it is difficult to talk about a permanent solution for this problem. 
Table 8: Top threats for business

\begin{tabular}{|l|l|l|}
\hline $\begin{array}{l}\text { Republic } \\
\text { of Serbia }\end{array}$ & $\begin{array}{l}\text { South-East } \\
\text { Europe (SEE) }\end{array}$ & $\begin{array}{l}\text { Central-East } \\
\text { Europe (CEE) }\end{array}$ \\
\hline $\begin{array}{l}\text { Social } \\
\text { instability } \\
(86 \%)\end{array}$ & $\begin{array}{l}\text { Geopolitical } \\
\text { crisis }(84 \%)\end{array}$ & $\begin{array}{l}\text { Geopolitical } \\
\text { crisis }(86 \%)\end{array}$ \\
\hline $\begin{array}{l}\text { Geopolitical } \\
\text { crisis }(81 \%)\end{array}$ & $\begin{array}{l}\text { Over-regulation } \\
(82 \%)\end{array}$ & $\begin{array}{l}\text { Government } \\
\text { response to fiscal } \\
\text { deficit and debt } \\
\text { burden }(81 \%)\end{array}$ \\
\hline $\begin{array}{l}\text { Over- } \\
\text { regulation } \\
(79 \%)\end{array}$ & $\begin{array}{l}\text { Government } \\
\text { response to fiscal } \\
\text { deficit and debt } \\
\text { burden (76\%) }\end{array}$ & $\begin{array}{l}\text { Over-regulation } \\
(77 \%)\end{array}$ \\
\hline
\end{tabular}

Source: PwC, 2016

The survey showed that the largest number of CEOs in Serbia introduce cost reduction as a strategic measure, even though there was a slight drop in this trend $(69 \%$ in 2016 versus $76 \%$ in 2015). However, the trend connected to this strategic measure is still very strong with other interviewees as well (68\% CEOs both globally and in the SEE region). Similar to last year, outsourcing certain business processes is one of top three most present measures in the process of company restructuring, while $24 \%$ of Serbian interviewees plan to complete a M\&A on the local/regional level. Making new strategic alliances is another strategic measure implemented by global CEOs (51\%) and SEE CEOs (32\%). This restructuring option is not high on the list of priorities among CEOs in Serbia, as only 19\% plan to establish new strategic alliances. (PwC, 2106).

CEOs understand that they have to adapt to new trends which demand a more significant engagement of them when it comes to meeting the demands of end users and stakeholders. From the company's point of view, the customers are the most important stakeholders which is why they design various activities in order to have better communication with them.

The survey has shown that as much as $93 \%$ of CEOs think the customers have a high or very high impact on their company's business strategy. Industry competitors come in second (cited by $76 \%$ of Serbian CEOs). What is interesting is that CEOs expect that in five years' time, an increasing number of customers will be demanding more than good prices and quality products from the companies - for them it will be increasingly more important in which ways the business impacts the wider society, (PwC, 2016). That was shown in practice through the application of corporate social responsibility (CSR) that includes all these issues of interest to the company, especially the issue of company relationship to the social community of which it is a part of. End users who have developed awareness of CSR are ready to buy products and services solely from the companies that take care of, for example, ethics, environmental protection, encourage social aims and the like.

The largest number of interviewees think that technological advancement is one of the three most present trends, which is also confirmed by Serbian CEOs (85\%) who implemented some/significant changes to the way they use new technology in order to improve their relationship with the clients. Every CEO in the survey says they are making changes to the way they use technology to assess and deliver on customer and stakeholder expectations. They state that the highest profit is made by technologies which enable data and analytics and social media communications and engagement, as well as customer/client relationship management systems (CRM) (PwC, 2016).

Young people (18-27 year-olds) expressed their opinion about domestic industry's competitiveness in a survey called 'The analysis of young people's attitudes and thoughts about starting your own business and implementing corporate social responsibility'. The survey was conducted from October to December 2016, on a sample of 553 students who opted for management studies. According to the interviewees' opinion, the necessary elements for developing domestic companies' competitive ability are: the application of contemporary management methods and techniques $21,67 \%$, standardising business quality $21,59 \%$ and building corporate social responsibility $14,09 \%$. The interviewed students are of the opinion that domestic companies' competitiveness is not on a very high level compared to the international surroundings, i.e. is not on a satisfying level $47,55 \%$ and is on a somewhat satisfying level $34,30 \%$. The students think that: education $11,03 \%$, financial support 9 , $44 \%$ and employee motivation $9,41 \%$ are the most important factors missing in the development of domestic companies' competitiveness. According to the students' opinion, the degree of innovation of domestic companies is somewhat satisfying $45,59 \%$, i.e. not satisfying $37,13 \%$. 


\section{CONCLUSION}

In global business conditions, the boundaries between industries and sectors are diminishing by the day and the traditional way of doing business is becoming inefficient. The application of new technologies is becoming the necessary element of companies' developmental strategies. Owing to the rapid development of ICT, a new economic model known as sharing economy is emerging which enables the end users to satisfy their new expectations. Compared to the previous period and the traditional way of doing business, the end users today can satisfy their needs in a much more efficient and financially affordable way. The application of ICT has enabled certain business processes to become faster and more efficient, which contributes to certain occupations becoming obsolete which in turn additionally influences the rise of unemployment. Owing to the digitalisation process new types of skills will be created which will contribute to the need for new skills and reemployment of the redundant workforce. The European Union is trying to lower its digital gap with other economies through encouraging the process of retraining in all industrial sectors. Transition countries in the conditions of new global economic trends, have to turn exclusively to the process of regionalisation as the only model applicable in their economies. In the case of the Republic of Serbia, the regionalisation strategy is aimed at three directions - joining the EU, CEFTA Agreement and cooperation with Eurasian countries. It is important that domestic economy cooperates with complementary economies, since it is the only way it can survive on the market. Furthermore, the process of globalisation itself does not offer the opportunities of sophisticated production to the Republic of Serbia, but directs its strategy to the manufacturing industry and the production of components.

The companies have to be ready for the $4^{\text {th }}$ industrial revolution and only those which realise on time that a new business model is arriving will be ready to survive on the market. The need for a more intensive application of ICT in business, faster and more efficient communication with end users, efficient data usage, finding new sources of financing, potentials of human relationship with the user, are all the segments the company has to be ready for if it wants to survive on the market. However, what is a great challenge for the manager in creating decision strategies is whether to turn to globalisation or regionalisation. For domestic and regional entrepreneurs it is best to focus on the regional strategy (Western Balkans, as well as the EU), since the markets are well-known to each other due to their historical, social, cultural and economic connectedness.

Young interviewees as future managers and business decision makers are not satisfied with domestic companies' competitiveness and they cite education, financial support and employee motivation as the key factors for its improvement. The issue of employee motivation and companies' relationship towards employees has still not become important in domestic companies while these issues are seriously dealt with in developed economies.

\section{REFERENCES}

Bogetić, S., Vidas-Bubanja, M., \& Lekić S. (2015, 1920nd June). Improving the quality of traffic companies aimed at competitiveness development. Paper presented at the V International symposium Engineering management and competitivness, Zrenjanin.

Brand Finance. (2017). Global 5002017 The annual report on the world's most valuable brands (February 2017 ed.): Brand Finance.

CEFTA. (2006). Sporazum o slobodnoj trgovini u Centralnoj Evropi, from http://www.pks.rs/PoslovnoOkruzenje.aspx?id=794 $\& p=1$

Cornell University, I., and WIPO (Producer). (2017, 01.10.2017). The Global Innovation Index 2017: Innovation Feeding the World, Ithaca, Fontainebleau, and Geneva Retrieved from http://www.wipo.int/edocs/pubdocs/en/wipo_pub_gi i_2017.pdf

Đorđević, D., Ćoćkalo, D., \& Bogetić, S. (2016). The analysis of marketing concept implementation in domestic enterprises. Journal of Engineering Management and Competitiveness (JEMC), 6(2), 120-128.

Đuričin, D., Janošević, S., \& Kaličanin, Đ. (2016). Menadžment i strategija. Beograd: Univerzitet u Beogradu Ekonomski fakultet, CID.

European Commission. (2017, 15.09.2017). Digital Transformation Scoreboard 2017: Evidence of positive outcomes and current opportunities for EU businesses. COSME programme of the European Union, from https://ec.europa.eu/growth/toolsdatabases/dem/

EuropeanCommission. (2016). Accelerating the digital transformation of European industry and enterprises. $D G$ Internal Market, Industry from $\mathrm{http} / / /$ ec.europa.eu/growth/sectors/digitaleconomy/entrepreneurship/strategic-policy-forum/ 
FederalTrade Commission. (2016). The "Sharing" Economy Issues Facing Platforms, Participants \& Regulators: A Federal Trade Commission Staff Report.

Fortune. The 100 Best Companies to Work For, from http://fortune.com/best-companies/

Ghemawat, P. (2010). Redefiniranje globalne strategije:Prevazilaženje granica u svetu u kojem su razlike još uvek važne. Zagreb: Mate.

Gurría, A., \& Mann, C. L. (2017). Better, but not good enough: OECD.

Hammer, M., \& Champy, J. (2004). Reinženjering tvrtke. Zagreb: Mate.

Hawksworth, J., Audino, H., \& Rob, C. (2017). The long view: how will the global economic order change by 2050 ? Retrieved 15.09.2017, from Price Waterhouse Coopers (PwC) https://www.pwc.com/gx/en/world-2050/assets/pwcworld-in-2050-summary-report-feb-2017.pdf

Kovačević, M., Pavlović, K., \& Šutić, V. (2016). Upotreba informaciono-komunikacionih tehnologija u Republici Srbiji (pp. 89). Beograd: Republički zavod za statistiku Srbije.

Mcardle, A. (2015). New Challenges in Digital Tourism. Brussels: General Counsel. EMEA.

Ministry of finance. (2017). Tekuća makroekonomska kretanja. Republika Srbija: Ministarstvo finansija, Sektor za makroekonomske i fiskalne analize i projekcije.

Mitkovska-Trendova, K., Minovski, R., \& Boshkovsk, i. D. (2014). Methodology for transition probabilities determination in a Markov decision processes model for quality-accuracy management. Journal of Engineering Management and Competitiveness (JEMC), 4(2), 59-67.
OECD, E. D. (2015). OECD Science, Technology and Innovation Directorate. The future of productivity: Preliminary version: The Secretary-General of the OECD.

Omae, K. (2007). Nova globalna pozornica: Izazovi $i$ prilike u svetu bez granica. Zagreb: Mate.

PwC. (2016). Redefinisanje pojma uspešnog poslovanja u svetu koji se menja, from www.pwc.com/ceosurvey

PwC. (2017). 20 years inside the mind of the CEO: What's next?, from http://www.pwc.com/gx/en/ceoagenda/ceosurvey/2017/rs

Schwab, K. (2017). Five leadership priorities for 2017. World economic forum, Annual meeting 2017

Davos, WEF, from

https://www.weforum.org/agenda/2017/01/fiveleadership-priorities-for-2017/

Schwieters, N., \& Moritz, B. (2017). 10 Principles for Leading the Next Industrial Revolution. https://www.strategy-business.com/article/10Principles-for-Leading-the-Next-IndustrialRevolution?gko $=\mathrm{f} 73 \mathrm{~d} 3$

SORS. (2017a). Spoljnotrgovinski robni promet avgust 2017. Statistika spoljne trgovine (Vol. LXVII). Beograd, Republika Srbija: Republički zavod za statistiku

SORS. (2017b). Spoljnotrgovinska robna razmena, januar 2017, saopštenje za javnost, from www.stat.gov.rs

Thompson, A. A. J., Sticland, A. J. I., \& Gamble, J. E. (2008). Strateški menadžment, Zagreb: Mate.

WEF. (2017). Opening plenary with Xi Jiping President of PR China. Annual meeting 2017 Davos, WEF: World Economic Forum.

\title{
NOVI POGLEDI NA STRATEGIJSKI MENADŽMENT
}

\begin{abstract}
Globalizacija predstavlja jedini ekonomski put nacionalnim ekonomijama širom sveta. Proces globalizacije je obeležen sledećim karakteristikama: neravnomerni privredni razvoj, intenzivna implementacija informaciono-komunikacionih tehnologija (IKT), razvoj inovacija, unapređenje produktivnosti, kao i neophodnost podizanja nivoa konkurentnosti. Kao rezultat sve veće primene IKT u poslovanju došlo je do uspostavljanja novog modela poslovanja sharing economy, koji je sve više zastupljen u praksi. Međutim, ove premene su značajno uticale i na same krajnje korisnike koji su sve zahtevniji u korišćenju interneta, pametnih telefona, tableta prilikom kupovine proizvoda ili usluga. U funkciji unapređenja konkurentnosti zemlje u razvoju moraju da prate promene globalnog tržišta, ali i da kreiraju sopstvene modele rasta svojih nacionalnih ekonomija. Osim nacionalnih ekonomija i preduzeća moraju da se prilagođavaju novonastalim trendovima. Preduzeća su danas pred velikim izazovima koje od njih postavljaju tržište, ali i krajnji korisnici.
\end{abstract}

Ključne reči: Strateški menadžment, Konkurentnost, Globalizacija, Informacione i komunikacione tehnologije, Poslovne strategije. 